\title{
Farmers' knowledge, perception and practices in soybean bacterial leaf pustule management in Benin
}

\author{
Gildas Codjo TCHEMADONa*, Valerien Amegnikin ZINSOUa, Rachidatou SIKIROUb, Moussa ZIME \\ SOKO N'DOUROa \\ aLaboratoire de Phytotechnie, d'Amélioration et de Protection des Plantes (LaPAPP), Université de Parakou (UP), BP \\ 123 Parakou, Benin. \\ bLaboratoire de Défense des Cultures, Centre de Recherches Agricoles d'Agonkanmey, Institut National des \\ Recherches Agricoles du Bénin (INRAB), Cotonou, Benin. \\ *Corresponding author Email: gildast092@yahoo.fr ; (+229) 66622781.
}

Original submitted in on $11^{\text {th }}$ December 2020. Published online at www.m.elewa.org/journals/ on $28^{\text {th }}$ February 2021 https://doi.org/10.35759/JABs.158.3

\begin{abstract}
Objective: This study aims to investigate the knowledge, perception and control strategies locally used by farmers against soybean bacterial leaf pustule in Benin.

Methodology and Results: An investigation was conducted on farmers' soybean knowledge, perception and practices (KPP) on the management of soybean bacterial leaf pustule in four Agro-Ecological Zones (AEZ) of Benin with high soybean production during August and September 2020. One hundred and sixty-eight (168) farmers were surveyed through face-to-face interviews using semi-structured questionnaire and visual observations in the field. After observing the disease symptoms through photos, about $69 \%$ of farmers asserted that soybean bacterial leaf pustule was present in their fields with low, medium or high incidences, from one to about ten years but the majority of farmers (85.4\%) do not consider it a disease. They perceived the disease symptoms at all stages of the plant's development with peak severity during the pre-flowering $(1.9 \%)$, flowering $(37.4 \%)$, and pod development (44.6\%). However, disease management was not performed by the majority of farmers with $100 \% ; 94.6 \% ; 91.9 \%$ and $73.3 \%$, in AEZ IV, III, V and II respectively. The reasons are lack of knowledge on management practices; the unavailability of effective pesticides and lack of financial resources. Pesticides were used by $26.5 \%, 8.1 \%$, and $5.4 \%$ in AEZ II, AEZ V and AEZ III respectively.

Conclusions and application of findings: They used pesticides in AEZ II, III and V; mainly insecticides in AEZ II. No control strategy is adopted in AEZ IV. Thus, to limit the use of chemical pesticides, especially insecticides, better information on integrated management of soybean bacterial leaf pustule is needed. In addition, the establishment of an efficient popularization system of the scientific research results is essential. Keywords: farmers' KPP, bacterial leaf pustule, soybean, management, Benin.
\end{abstract}

\section{INTRODUCTION}

Soybean (Glycine max (L.) Merr.) is one of the main oilseed crops commonly grown in the world. Soybean is the first oilseed crop produced in the world with a production of around 336.11 million tons in 2019 (Shahbandeh, 2020). In Benin, its production increased from 32,446 to 221,977 tons between 2008 and 2018 (FAOSTAT, 2020) which correspond to more than $584 \%$ of increasing in a decade. Soybean production is exposed to a wide range of biotic and abiotic constraints, which affect 
negatively its production through direct reduction in grain yields and / or seed quality (Hartman et al., 2011). Indeed, soybean farmers must take up the challenge of unpredictable weather conditions, weeds, variability in soil quality, pests and diseases (Lal, 2009; Strange and Scott, 2005). Soybean bacterial leaf pustule caused by Xanthomonas axonopodis pv. glycines is among the most important soybean diseases worldwide. Prathuangwong and Amnuaykit (1987) reported significant yield losses in the range of $20-35 \%$, as well as a reduction in seed quality following infection of soybean bacterial leaf pustule. As this disease is associated with cultivation in most soybean production areas, it was also reported in Benin by Zinsou et al. (2015a; b) in $72.2 \%$ and $97 \%$ of the fields surveyed respectively in the Sudanese and Guinean savannas. In addition, Zinsou et al. (2016)

\section{MATERIALS AND METHODS}

Study area: A survey was carried out in the four (04) main agro-ecological zones (AEZ) of soybean production (AEZ II, III, IV and V) in Benin. According to MCVDD (2020) and Chabi et al. (2019), the AEZ II called Cotton Zone of North Benin includes the townships of Banikoara, Kerou, Kandi, Segbana and Gogounou and is located between a latitude of 10.5 and $12^{\circ}$. It is characterized by a cropping season, which extends from May to September, a more or less sandy tropical ferruginous soil, a rainfall of $900-1000 \mathrm{~mm}$ and a temperature varying from 28 to $45^{\circ} \mathrm{C}$. The AEZ III (South Borgou Food Zone), is located between $1^{\circ} 10^{\prime}-3^{\circ} 45^{\prime} \mathrm{E}$ and $9^{\circ} 45^{\prime}-12^{\circ} 25^{\prime} \mathrm{N}$ and includes the townships of Nikki, Perere, Kalale, Bembereke, N'Dali, Sinende, Pehunco and Kouande. Located in the Sudanese zone of Benin, this AEZ has a unimodal rainfall regime with an average annual rainfall less than $1000 \mathrm{~mm}$. The relative humidity varies from 18 to $99 \%$ while temperature fluctuates from 24 to $31^{\circ} \mathrm{C}$. The Ferric and Plintic Luvisol (FAO, 2006) are the dominant soil types. The AEZ IV called West Atacora Zone brings together the townships of Tanguieta, Cobly, Materi, Natitingou, Toucountouna, Boukoumbe, Copargo, Ouake and Djougou. It benefiting from the presence of the Atacora range, which gives it a special climate where temperatures are cool and storms more frequent than in other areas. Rainfall varies from 800 to $1350 \mathrm{~mm}$ depending on the year. The Cotton Zone of Central Benin (AEZ V), located between $1^{\circ} 45^{\prime}$ $2^{\circ} 24^{\prime} \mathrm{E}$ and $6^{\circ} 25^{\prime}-7^{\circ} 30^{\prime} \mathrm{N}$ and encompasses the entire indexed this disease as responsible for yield losses ranging from 2.7 to $28.1 \%$ in Benin. A decade after the various studies carried out on soybean in Benin related to the distribution of soybean diseases and pathogens characterization in 2011 and 2012 by Zinsou et al. (2015a; b) and to control strategies such as the shift in sowing dates in 2011 and 2012 (Zinsou et al., 2015c) and the selection of resistant varieties in 2012 and 2013 (Zinsou et al., 2016), soybean bacterial leaf pustule and its management is still not well known by farmers. For the development of efficient integrated disease management strategies adapted to the needs of local farmers, knowledge of traditional management practices is needed. Thus, this study aims to investigate the knowledge, perception and control strategies locally used by farmers against soybean bacterial leaf pustule in Benin.

Collines Department and part of a few Departments (Borgou, Donga, Couffo, Plateau and Zou). The area is under the sudano-guinean zone also call transitional zone of Benin. The average annual temperature is between $26-29^{\circ} \mathrm{C}$ and the average annual rainfall ranges from 1000 to $1400 \mathrm{~mm}$. The relative humidity varies from 69 to $97 \%$. The Ferric and Plintic Luvisol are also the dominant soil types in the area. Black and hydromorphic soils are also found in the rivers' valleys.

Sample selection: The number and the list of soybean farmers by townships was obtained from PADA (West Africa Agricultural Productivity Program) and Townships Soybean Farmers' Unions. Thus, 168 soybean farmers were surveyed (Table 1). The surveyed soybean farmers were sampled based on a multi-stage random sampling procedure (Schreinemachers et al., 2015). Within each of the four agro-ecological zones, three townships were selected based on their production potential (high, medium, low); a total of 12 townships were surveyed. The sample size ( $N=$ number of farmers to be interviewed) was determined by applying a coefficient ( $\mathrm{k}$ $=2 \%$ ) to the number of registered farmers in each of the 12 townships considered.

$$
\mathrm{N}=\mathrm{k} \cdot \sum_{i=1}^{12} n_{i}
$$

Where, $\mathrm{N}=$ required sample size $\mathrm{k}=$ coefficient applied $(2 \%), n_{i}=$ number of soybean registered farmers in each of the townships considered. 
Table 1: Distribution of surveyed farmers by AEZ and Township

\begin{tabular}{c|c|c|c}
\hline $\begin{array}{c}\text { Agro-ecological zones } \\
\text { (AEZ) }\end{array}$ & Communes & $\begin{array}{c}\text { Number of farmers } \\
\text { interviewed }\end{array}$ & Total \\
\hline $\begin{array}{c}\text { Cotton Zone of North Benin } \\
\text { (AEZ II) }\end{array}$ & Gogounou & 05 & 49 \\
& Kandi & 13 & \\
Segbana & 31 & 56 \\
South Borgou Food Zone & Kouande & 17 & \\
(AEZ III) & N'Dali & 19 & 26 \\
West Atacora Zone (AEZ IV) & Bembereke & 20 & \\
& Natitingou & 08 & 37 \\
\hline Cotton Zone of Central Benin & Djougou & 09 & 168 \\
(AEZ V) & Glazoue & 09 & 11 \\
\hline Total & Tchaourou & 12 & 14 \\
\hline
\end{tabular}

Data collection: Data were collected through face-toface interviews and visual observations in the field. For this reason, a semi-structured questionnaire was developed based on the socio-demographic characteristics of the farmers, the characteristics of their fields, the constraints linked to soybean production, the expression of soybean bacterial leaf pustule and the management strategies against the disease. At the beginning of the interview, the purpose of the study was introduced. During the interviews, photographs of soybean plants showing symptoms of bacterial pustule (Xanthomonas axonopodis pv. glycines), bacterial blight (Pseudomonas syringae pv. glycinea) and rust (Phakopsora pachyrhizi) of soybean were presented to the farmers in order to avoid any confusion, since these diseases present similar symptoms with a few

\section{RESULTS}

Socio-demographic characteristics of soybean farmers: The soybean farmers interviewed were $78.1 \%$ men against $21.9 \%$ women. No significant difference was observed between the age groups $(X 2=18.96 ; P=$ 0.090 ) on the one hand and the education levels of the farmers ( $X 2=13.36 ; P=0.343$ ) on the other. However, $37.2 \%$ of farmers belonged to the age group (29 to 39 years) and $44.6 \%$ had no education. The majority of farmers surveyed $(79.5 \%)$ have soybean area between differences. Some neighbouring soybean fields were visited if necessary.

Data analysis: Quantitative and qualitative data collected through the questionnaires, were coded and subjected to statistical analyses using $\mathrm{R}$ software version 3.6.1. From descriptive statistics, cross tables were constructed to summarize the data from the questionnaires. To make statistical inferences, contingency Chi-square tests followed by a Student's t test, an analysis of variance (ANOVA) at the $5 \%$ level and an SNK test (in the event of a significant difference) were carried out to analyse relationships between variables. Empirical analyses and the linkage between the parameters collected across the four agro-ecological zones considered were also performed.

1 and 5 ha. About 70\%, produced soybean for 1 to 5 years. No significant difference was noted between the sources of seed supply ( $X 2=6.46 ; P=0.091)$. Nevertheless, $95.2 \%$ of the farmers buy their seeds at the market, unlike $4.8 \%$ who prefer seeds from approved structures. The majority of farmers $(74.9 \%)$ adopt conventional farming, in contrast to the $25.1 \%$ who engage in organic farming (Table 2). 
Table 2: Socio-demographic characteristics of the surveyed farmers

\begin{tabular}{|c|c|c|c|c|c|c|c|c|}
\hline \multirow[t]{2}{*}{ Characteristics } & \multicolumn{4}{|c|}{ Percentage of farmers } & \multirow[b]{2}{*}{ Mean } & \multirow[b]{2}{*}{ df } & \multirow[b]{2}{*}{$x^{2}$} & \multirow[b]{2}{*}{ P-value } \\
\hline & $\begin{array}{l}\text { AEZ II } \\
(n=49)\end{array}$ & $\begin{array}{l}\text { AEZ III } \\
(n=56)\end{array}$ & $\begin{array}{l}\text { AEZ IV } \\
(n=26)\end{array}$ & $\begin{array}{l}\text { AEZ V } \\
(n=37)\end{array}$ & & & & \\
\hline $\begin{array}{l}\text { Sex of farmer } \\
\text { Male } \\
\text { Female }\end{array}$ & $\begin{array}{l}71.4 \\
28.6\end{array}$ & $\begin{array}{l}78.6 \\
21.4\end{array}$ & $\begin{array}{l}73.1 \\
26.9\end{array}$ & $\begin{array}{l}89.2 \\
10.8\end{array}$ & $\begin{array}{l}78.1 \\
21.9\end{array}$ & 3 & 4.31 & 0.230 \\
\hline $\begin{array}{l}\text { Age of farmer (years) } \\
18-28 \\
29-39 \\
40-50 \\
51-61 \\
>61\end{array}$ & $\begin{array}{l}36.7 \\
38.8 \\
16.3 \\
8.2 \\
0.0\end{array}$ & $\begin{array}{l}14.3 \\
41.1 \\
23.2 \\
12.5 \\
8.9\end{array}$ & $\begin{array}{c}23.1 \\
23.1 \\
23.1 \\
26.9 \\
3.8\end{array}$ & $\begin{array}{l}16.2 \\
45.9 \\
21.6 \\
10.8 \\
5.5\end{array}$ & $\begin{array}{l}22.6 \\
37.2 \\
21.1 \\
14.6 \\
4.5\end{array}$ & 12 & 18.96 & 0.090 \\
\hline $\begin{array}{l}\text { Education level } \\
\text { None } \\
\text { Adult education } \\
\text { Primary } \\
\text { Secondary } \\
\text { Higher }\end{array}$ & $\begin{array}{c}38.8 \\
10.2 \\
16.3 \\
30.6 \\
4.1\end{array}$ & $\begin{array}{c}57.1 \\
8.9 \\
12.5 \\
16.1 \\
5.4\end{array}$ & $\begin{array}{c}50.0 \\
0.0 \\
11.5 \\
38.5 \\
0.0\end{array}$ & $\begin{array}{c}32.4 \\
10.8 \\
16.2 \\
32.4 \\
8.2\end{array}$ & $\begin{array}{c}44.6 \\
7.5 \\
14.1 \\
29.4 \\
4.4\end{array}$ & 12 & 13.36 & 0.343 \\
\hline $\begin{array}{l}\text { Size of the soybean farm (ha) } \\
<1 \\
1-5 \\
6-10 \\
11-15\end{array}$ & $\begin{array}{l}2.0 \\
81.6 \\
14.4 \\
2.0\end{array}$ & $\begin{array}{l}17.9 \\
71.4 \\
10.7 \\
0.0\end{array}$ & $\begin{array}{c}26.9 \\
73.1 \\
0.0 \\
0.0\end{array}$ & $\begin{array}{l}5.4 \\
91.9 \\
2.7 \\
0.0\end{array}$ & $\begin{array}{c}13.1 \\
79.5 \\
6.9 \\
0.5\end{array}$ & 9 & 21.72 & 0.010 \\
\hline $\begin{array}{l}\text { Experience in soybean farming } \\
\text { (years) } \\
1-5 \\
6-10 \\
11-15 \\
16-20 \\
>20\end{array}$ & $\begin{array}{c}67.4 \\
30.6 \\
0.0 \\
2.0 \\
0.0\end{array}$ & $\begin{array}{l}73.2 \\
21.4 \\
3.6 \\
1.8 \\
0.0\end{array}$ & $\begin{array}{c}84.6 \\
3.8 \\
7.7 \\
0.0 \\
3.8\end{array}$ & $\begin{array}{l}51.4 \\
32.4 \\
8.1 \\
8.1 \\
0.0\end{array}$ & $\begin{array}{c}69.1 \\
22.1 \\
4.9 \\
3.0 \\
0.9\end{array}$ & 12 & 23.53 & 0.024 \\
\hline $\begin{array}{l}\text { Sources of seed supply } \\
\text { Market } \\
\text { Approved structures }\end{array}$ & $\begin{array}{l}89.8 \\
10.2\end{array}$ & $\begin{array}{c}91.1 \\
8.9\end{array}$ & $\begin{array}{c}100.0 \\
0.0\end{array}$ & $\begin{array}{c}100.0 \\
0.0\end{array}$ & $\begin{array}{c}95.2 \\
4.8\end{array}$ & 3 & 6.46 & 0.091 \\
\hline $\begin{array}{l}\text { Type of farming } \\
\text { Conventional } \\
\text { Organic }\end{array}$ & $\begin{array}{c}98.0 \\
2.0 \\
\end{array}$ & $\begin{array}{l}85.7 \\
14.3 \\
\end{array}$ & $\begin{array}{l}53.8 \\
46.2 \\
\end{array}$ & $\begin{array}{l}62.2 \\
37.8 \\
\end{array}$ & $\begin{array}{l}74.9 \\
25.1 \\
\end{array}$ & 3 & 28.54 & $2.8 .10^{-6}$ \\
\hline
\end{tabular}

Note: $\mathrm{df}=$ degree of freedom, $\mathrm{X}^{2}=$ Chi square test, $\mathrm{P} \leq 0.05$ shows there was a significant difference.

Soybean production constraints with particular emphasis on soybean bacterial leaf pustule: The constraints related to soybean production mentioned by the farmers are presented in Table 3. These are diseases, pests, drought, weeds, lack of knowledge on production techniques, lack of access to inputs, late sowing, low soil fertility and various others such as: lack of financial resources, the arduousness of the sowing operations but also of threshing and winnowing of harvested products, the low level of soybean sales prices, the difficult access to the soybean market, flooding and poor quality of seeds. According to the interviewees, weeds $(34.5 \%)$ represent the main constraint affecting soybean production. No significant difference $(X 2=7.49 ; P=0.058$ ) was recorded in the recognition or not of soybean bacterial leaf pustule. However, it should be noted that $85.4 \%$ of farmers do not recognize soybean bacterial leaf pustule as a disease. No significant differences were also noted for the parameters: observation or not of the soybean bacterial leaf pustule by the farmers in their fields $(X 2=6.75 ; P=$ $0.080)$; disease incidence ( $X 2=10.55 ; P=0.308)$; number of years since which they have observed the symptoms of the disease $(X 2=19.13 ; P=0.086)$; the 
growth stage from which they observed the first symptoms of the disease $(X 2=11.98 ; P=0.214)$ and the severity of the disease $(X 2=8.53 ; P=0.482)$. Nevertheless, $68.8 \%$ of the interviewed farmers observed the symptoms of the disease in their fields; $43.9 \%$ report it with a low incidence $(0-25 \%)$ and $40.3 \%$ reported the appearance of the disease 1 to 2 years ago. In addition, $55.0 \%$ of farmers affirmed that the first symptoms of the disease are observed during the flowering stage and $44.6 \%$ note that the disease is most severe during the pod development.

Table 3: Soybean production constraints and soybean bacterial leaf pustule history

\begin{tabular}{|c|c|c|c|c|c|c|c|c|}
\hline \multirow[t]{2}{*}{ Constraints and SBLP history } & \multicolumn{4}{|c|}{ Percentage of farmers } & \multirow[b]{2}{*}{ Mean } & \multirow[b]{2}{*}{ df } & \multirow[b]{2}{*}{$x^{2}$} & \multirow[b]{2}{*}{ P-value } \\
\hline & $\begin{array}{l}\text { AEZ II } \\
(n=49)\end{array}$ & $\begin{array}{l}\text { AEZ III } \\
(n=56)\end{array}$ & $\begin{array}{r}\text { AEZ IV } \\
(n=26)\end{array}$ & $\begin{array}{l}\text { AEZ V } \\
(n=37)\end{array}$ & & & & \\
\hline $\begin{array}{l}\text { Soybean production constraints } \\
\text { Diseases } \\
\text { Pests } \\
\text { Drought } \\
\text { Weeds } \\
\text { Lack of knowledge on production } \\
\text { techniques } \\
\text { Lack of access to inputs } \\
\text { Late sowing } \\
\text { Low soil fertility } \\
\text { Other }\end{array}$ & $\begin{array}{c}87.8 \\
46.9 \\
91.8 \\
93.9 \\
0.0 \\
49.0 \\
71.4 \\
83.7 \\
12.2\end{array}$ & $\begin{array}{c}80.4 \\
37.5 \\
71.4 \\
80.4 \\
3.6 \\
48.2 \\
53.6 \\
69.6 \\
7.1\end{array}$ & $\begin{array}{c}84.6 \\
34.6 \\
80.8 \\
96.2 \\
0.0 \\
50.0 \\
38.5 \\
61.5 \\
26.9\end{array}$ & $\begin{array}{c}86.5 \\
59.5 \\
100.0 \\
100.0 \\
10.8 \\
83.8 \\
81.1 \\
86.5 \\
27.0\end{array}$ & $\begin{array}{c}84.8 \\
44.6 \\
86.0 \\
92.6 \\
3.6 \\
57.8 \\
61.2 \\
75.3 \\
18.3\end{array}$ & & & \\
\hline $\begin{array}{l}\text { Main constraint in soybean } \\
\text { production } \\
\text { Diseases } \\
\text { Pests } \\
\text { Drought } \\
\text { Weeds } \\
\text { Lack of access to inputs } \\
\text { Late sowing } \\
\text { Low soil fertility } \\
\text { Other }\end{array}$ & $\begin{array}{c}4.1 \\
4.1 \\
6.1 \\
42.9 \\
22.4 \\
0.0 \\
8.2 \\
12.2\end{array}$ & $\begin{array}{c}5.4 \\
5.4 \\
10.7 \\
26.8 \\
14.2 \\
8.9 \\
23.2 \\
5.4\end{array}$ & $\begin{array}{c}0.0 \\
7.7 \\
7.7 \\
38.5 \\
3.8 \\
0.0 \\
11.5 \\
30.8\end{array}$ & $\begin{array}{c}2.8 \\
0.0 \\
13.5 \\
29.7 \\
16.2 \\
0.0 \\
13.5 \\
24.3\end{array}$ & $\begin{array}{c}3.1 \\
4.3 \\
9.5 \\
34.5 \\
14.2 \\
2.2 \\
14.1 \\
18.2\end{array}$ & 21 & 35.84 & 0.023 \\
\hline $\begin{array}{l}\text { Recognition of SBLP as disease } \\
\text { by farmers } \\
\text { Yes } \\
\text { No }\end{array}$ & $\begin{array}{l}14.3 \\
85.7\end{array}$ & $\begin{array}{l}19.6 \\
80.4\end{array}$ & $\begin{array}{l}0.0 \\
100\end{array}$ & $\begin{array}{l}24.3 \\
75.7\end{array}$ & $\begin{array}{l}14.6 \\
85.4\end{array}$ & 3 & 7.49 & 0.058 \\
\hline $\begin{array}{l}\text { SBLP in farmer's field } \\
\text { Observed } \\
\text { Not observed }\end{array}$ & $\begin{array}{l}63.3 \\
36.7\end{array}$ & $\begin{array}{l}58.9 \\
41.1\end{array}$ & $\begin{array}{l}69.2 \\
30.8 \\
\end{array}$ & $\begin{array}{l}83.8 \\
16.2 \\
\end{array}$ & $\begin{array}{l}68.8 \\
31.2\end{array}$ & 3 & 6.75 & 0.080 \\
\hline $\begin{array}{l}\text { Incidence of SBLP in farmer's } \\
\text { field }(\%) \\
\text { No } \\
\text { Low }(0-25) \\
\text { Medium }(25-50) \\
\text { High }(>50)\end{array}$ & $\begin{array}{l}36.7 \\
42.9 \\
14.3 \\
6.1\end{array}$ & $\begin{array}{c}41.1 \\
39.3 \\
10.7 \\
8.9\end{array}$ & $\begin{array}{l}30.8 \\
50.0 \\
11.5 \\
7.7\end{array}$ & $\begin{array}{l}16.2 \\
43.2 \\
24.4 \\
16.2\end{array}$ & $\begin{array}{l}31.2 \\
43.9 \\
15.2 \\
9.7\end{array}$ & 9 & 10.55 & 0.308 \\
\hline $\begin{array}{l}\text { First time SBLP observed in the } \\
\text { field } \\
\geq 10 \text { years ago } \\
5-9 \text { years ago } \\
3-4 \text { years ago } \\
1-2 \text { years ago }\end{array}$ & $\begin{array}{c}0.0 \\
18.4 \\
16.3 \\
44.9\end{array}$ & $\begin{array}{c}1.8 \\
7.2 \\
37.5 \\
33.9\end{array}$ & $\begin{array}{c}0.0 \\
0.0 \\
19.2 \\
50.0\end{array}$ & $\begin{array}{l}5.4 \\
16.2 \\
27.0 \\
32.4\end{array}$ & $\begin{array}{c}1.8 \\
10.5 \\
25.0 \\
40.3\end{array}$ & 12 & 19.13 & 0.086 \\
\hline
\end{tabular}


Tchemadon et al., J. Appl. Biosci. 2021 Farmers' knowledge, perception and practices in soybean bacterial leaf pustule management in Benin

\begin{tabular}{l|c|c|c|c|c|c|c|c} 
I don't remember & 20.4 & 19.6 & 30.8 & 19.0 & 22.5 & & & \\
\hline $\begin{array}{l}\text { Growth stage with first symptoms } \\
\text { of SBLP }\end{array}$ & & & & & & & & \\
Pre-flowering & 18.4 & 21.4 & 7.7 & 16.2 & 15.9 & 9 & 11.98 & 0.214 \\
Flowering & 59.2 & 46.4 & 57.7 & 56.8 & 55.0 & & & \\
Pod development & 14.3 & 21.4 & 7.7 & 8.1 & 12.9 & & & \\
Don't know & 8.1 & 10.8 & 26.9 & 18.9 & 16.2 & & & \\
\hline Growth stage with high SBLP & & & & & & & & \\
severity & & & & & & & & \\
Pre-flowering & 4.1 & 3.6 & 0.0 & 0.0 & 1.9 & 9 & 8.53 & 0.482 \\
Flowering & 38.8 & 39.3 & 30.8 & 40.5 & 37.4 & & & \\
Pod development & 49.0 & 46.4 & 42.3 & 40.5 & 44.6 & & & \\
Don't know & 8.1 & 10.7 & 26.9 & 19.0 & 16.2 & & & \\
\hline Not: df=degree
\end{tabular}

Note: $\mathrm{df}=$ degree of freedom, $\mathrm{X}^{2}=$ Chi square test, $\mathrm{P} \leq 0.05$ shows there was a significant difference.

Management of soybean bacterial leaf pustule by famers: Hundred percent (100\%); $73.3 \% ; 94.6 \%$ and $91.9 \%$ of farmers, from agro-ecological zones IV, II, III and $\mathrm{V}$ respectively, do not adopt any strategy to control the soybean bacterial leaf pustule (Figure 1). Although there is no significant difference between the reasons given by the farmers to justify the non-application of management strategies $(X 2=6.97 ; P=0.640)$. The reasons are lack of knowledge on management practices (63.4\%); cost and unavailability of effective pesticides (19.4\%); lack of knowledge on management practices and cost and unavailability of effective pesticides $(16.5 \%)$ and lack of financial resources $(0.7 \%)$ (Table 4). However, it is noted that in the AEZ II, 24.5\% and $2.0 \%$ of farmers used insecticides and herbicides to manage the disease, respectively. In AEZ III, insecticides, herbicides and petroleum are applied by $1.8 \%$ of farmers. In $A E Z \mathrm{~V}, 8.1 \%$ of farmers used only insecticides to control the disease.

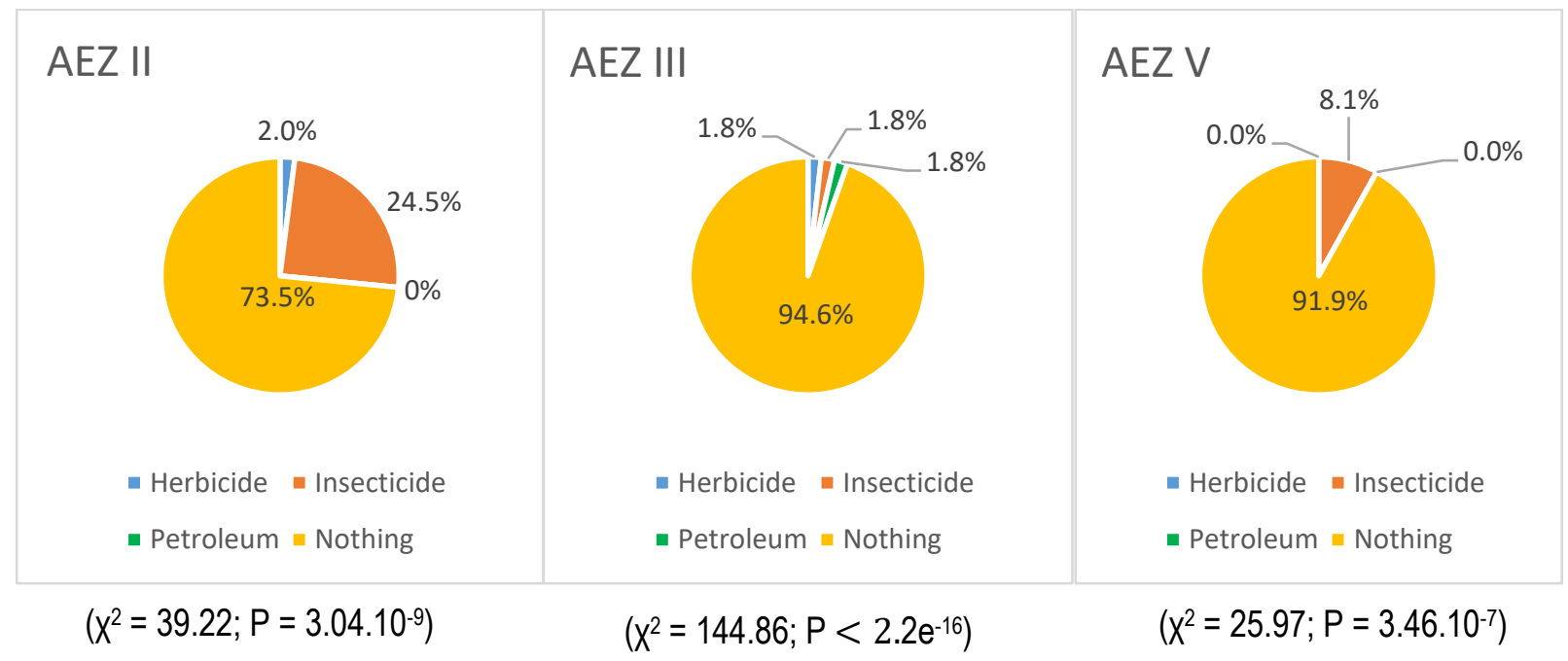

Figure 1: Management strategies for soybean bacterial leaf pustule in AEZ II; III and V 
Table 4: Possible reasons justifying the non-application of management methods for soybean bacterial leaf pustule in the study area

\begin{tabular}{|c|c|c|c|c|c|c|c|c|}
\hline \multirow[t]{2}{*}{ Reasons } & \multicolumn{4}{|c|}{ Percentage of farmers } & \multirow[b]{2}{*}{ Mean } & \multirow[b]{2}{*}{ df } & \multirow[b]{2}{*}{$x^{2}$} & \multirow[b]{2}{*}{ P-value } \\
\hline & $\begin{array}{l}\text { AEZ II } \\
(n=49)\end{array}$ & $\begin{array}{l}\text { AEZ III } \\
(n=56)\end{array}$ & $\begin{array}{l}\text { AEZ IV } \\
(n=26)\end{array}$ & $\begin{array}{l}\text { AEZ V } \\
(n=37)\end{array}$ & & & & \\
\hline $\begin{array}{l}\text { Lack of knowledge on } \\
\text { management practices }\end{array}$ & 61.1 & 62.3 & 65.4 & 64.7 & 63.4 & 9 & 6.97 & 0.640 \\
\hline $\begin{array}{l}\text { Cost and unavailability of effective } \\
\text { pesticides }\end{array}$ & 27.8 & 20.8 & 11.5 & 17.6 & 19.4 & & & \\
\hline $\begin{array}{l}\text { Lack of knowledge on } \\
\text { management practices + Cost } \\
\text { and unavailability of effective } \\
\text { pesticides }\end{array}$ & 11.1 & 17.0 & 23.1 & 14.7 & 16.5 & & & \\
\hline Other & 0.0 & 0.0 & 0.0 & 2.9 & 0.7 & & & \\
\hline
\end{tabular}

Note: $\mathrm{df}=$ degree of freedom, $\mathrm{X}^{2}=$ Chi square test, $\mathrm{P} \leq 0.05$ shows there was a significant difference.

\section{DISCUSSION}

Diseases, pests, drought, weeds, lack of knowledge on production techniques, inputs, financial resources, late sowing, low soil fertility, difficult sowing operations, threshing and winnowing of crop harvest products, low level of soybean prices, difficult access to the soybean market, flooding and poor quality of seeds represent the soybean production constraints noted through this study. Various authors have also reported these same factors. Indeed, diseases, pests (Mbanya, 2011); drought (Hufstetler et al., 2007); weeds, lack of knowledge, inputs, financial resources, low selling prices for soybean, poor seed quality (Otitoju and Arene, 2010), and difficult access to the soybean market (Mohammed et al., 2018) have been shown to hold back soybean production around the world. Weeds represent the main constraint underlined by the farmers during this study. These results corroborate those of Vivian et al. (2013). Indeed, according to these authors, weeds are considered as the number one problem in all soybeanproducing countries. So even with advanced technologies, growers notice the high yield losses due to weed interference. According to Norris (1999), uncontrolled weeds not only reduce soybean yields due to their competition for light, nutrients and moisture, but they can also significantly reduce harvest efficiency and seeds quality. In addition, the presence of weeds in soybean fields increases production costs (Buhler and Hartzler, 2004). Oerke and Dehne (2004) demonstrated that weeds cause soybean yield loss of $37 \%$. In the United States, weeds are considered to cause losses of several million of US dollars annually (Vivian et al., 2013). About $69 \%$ of the farmers observe the soybean bacterial leaf pustule symptoms on their fields with incidence varying between 0 and more than $50 \%$. Most of farmers $(85.4 \%)$ do not recognize the soybean bacterial leaf pustule as a disease. The same observation was made by Medat et al. (2016), who revealed that in the south Gujarat (India), the $82.64 \%$ of the soybean growers lacked of knowledge on the disease identification. Echodu et al. (2019) also showed that sweet potato growers in four East African countries were unable to associate diseases to symptoms. In addition, Schreinemachers et al. (2015) studied farmers' perceptions and management of plant viruses in vegetables and legumes in India, Thailand and Vietnam and found that very few farmers were able to associate the typical disease symptoms with plant viruses and even fewer knew the role of whiteflies (Aleyrodidae) and thrips (Thysanoptera) as vectors and even ignore that these insects should be controlled to manage diseases on their fields. These studies show that farmers' lack of important knowledge about pests and diseases and this matter harms to the crop performance (Islam et al., 2020). According to Riley et al. (2002), control measures depend on correct identification of the diseases and causal agents. Without proper identification of the disease, control measures could be a waste of time and money and could result in further plant losses. Up to $40.3 \%$ of farmers noticed the disease symptoms for more than 1 to 10 years. These results corroborate those of Zinsou et al. (2015a; b) who, reported in 2011 and 2012 the presence of soybean bacterial leaf pustule in Benin. Also, according to AEZ, $12.9 \%$ to $55.0 \%$ of farmers affirm that the first symptoms of the disease are observed, respectively, before flowering; during the flowering and pod development. These results are in 
agreement with those of Prathuangwong et al. (2001), who state that the disease can affect soybean at all stages of plant development. All or the majority of interviewed farmers, depending on the agro-ecological zone, do not adopt any strategy to control the soybean bacterial leaf pustule and give lack of knowledge on management practices, the cost and unavailability of effective pesticides; the lack of knowledge on management practices + the cost and unavailability of effective pesticides and finally, the lack of financial resources as justification. The same remark was made in Benin by Tonon et al. (2018), who reported that although cashew growers claim that anthracnose in cashew has been occurring for at least 5 years, they have adopted no control method. Additionally, in Tanzania, Hashim et al. (2018) showed that although the severity of rice blast has increased year by year over the past 3 to 10 years, most of rice growers have barely adopted disease management methods in their fields. According to these authors, the constant increase in the abundance of rice blast could therefore be attributed to the lack of information and knowledge about the disease but also to the high cost and unavailability of effective fungicides. However, it should be noted that the AEZ II farmers in our study, use at $24.5 \%$ and $2.0 \%$, respectively, insecticides and herbicides in the management of the disease. In AEZ III, insecticides; herbicides and petroleum are each applied by $1.8 \%$ of farmers. With regard to $A E Z V$, only insecticides are used by $8.1 \%$ of farmers in order to control the disease. Chemical control based on insecticide products has proven to be the main control strategy used by these

\section{CONCLUSION}

Among the various constraints affecting soybean production, most of the farmers have observed the symptoms of soybean bacterial leaf pustule in their fields with varying incidences, for one to ten years, or more. Symptoms appear at all growing stages of plant with peak severity at the pod development. However, the disease management was not performed by most of the farmers because of lack of knowledge on management practices; the cost and unavailability of effective pesticides and to a lesser extent the lack of financial farmers. This state of affairs testifies to the lack of knowledge or ignorance of producers who apply insecticides instead of fungicides or bactericides in the disease control. This could also be explained by the lack, or even the absence, of fungicides or bactericides approved in Benin for the fight against soybean diseases. Indeed, in Benin, Mancozeb 80WP and Copper Hydroxide 65.6WP are respectively the two fungicides and fungicides-bactericides approved for the management of pathologies on market garden and food crops (CNGP-BENIN, 2020). In addition, this study noted a strong use of insecticides $(24.5 \%$ and $8.1 \%)$ in the management of the disease, respectively in AEZ II (Cotton zone of north Benin) and AEZ V (Cotton zone of central Benin) compared to AEZ III (South Borgou food zone) where it is $1.8 \%$. This state of affairs could be explained by the fact that the farmers of $A E Z$ II and V, belonging to the cotton zones, have easy access to the cotton insecticides made available to them within the framework of the protection of the cotton fields against the attacks of many crop pests. Indeed, in Benin, more than $70 \%$ of registered pesticides are insecticide products intended for cotton growing (CNGP-BENIN, 2020). Finally, although the shift in sowing dates and the use of resistant varieties were respectively recommended by Zinsou et al. (2015c) and Zinsou et al. (2016), farmers did not adopt these strategies. This state of affairs could be explained by the lack of an effective system for disseminating research results through advice and support structures for farmers.

resources. Some farmers adopted use of insecticides to control the disease mainly in the large cotton-growing areas of Benin where others use organic farming. Thus, to limit the use of chemical pesticides, especially insecticides, better information on integrated management of soybean bacterial leaf pustule is needed. Also, the establishment of an efficient popularization system of the scientific research results is essential.

CONFLICT OF INTEREST: The authors declare no conflict of interest.

ACKNOWLEDGEMENTS: The authors are grateful to the farmers who participated in this study. 


\section{REFERENCES}

Buhler D. D., Hartzler R. G. 2004. Weed biology and management. In: Boerma, H.R., Specht, J.E. (Eds.). Soybeans: Improvement, Production and Uses. ASA, CSSA and SSSA Inc., Madison, Wisconsin, USA, pp. 883-909.

Chabi F. O., Dagbenonbakin G. D., Agbangba C. E., Oussou B., Amadji G. L., Ahoton E. L., Saïdou A. 2019. Soil fertility level and cropping practices determining soybean yield in northern east and center of Benin. International Journal of Plant \& Soil Science. 30(6):1-10. ISSN: 23207035.

CNGP-BENIN (Comité National de Gestion des Pesticides). 2020. Liste des pesticides et biopesticides sous autorisation provisoire de vente (APV) et agrément homologation (AH). $7 p$.

Echodu R., Edema H., Wokorach G., Zawedde C., Otim G., Luambano N., Ateka E. M., Asiimwe T. 2019. Farmers' practices and their knowledge of biotic constraints to sweet potato production in East Africa. Physiol. Mol. Plant Pathol. 105:316.

FAO. 2006. World reference base for soil resources, by FAO-UNESCO-ISRIC. World Soil Resources Report NFAO, Rome.

FAOSTAT (Food and Agriculture Organization of the United Nations). 2020. Soybean production data. Retrieved September 30, 2020, from http://www.fao.org/faostat/fr/\#data/QC.

Hartman G. L., West E. D., Herman T. K. 2011. Crops that feed the World 2. Soybean -worldwide production, use, and constraints caused by pathogens and pests. Food Sec. 3:5-17. DOI 10.1007/s12571-010-0108-x.

Hashim I., Mamiro D. P., Mabagala R. B., Tefera T. 2018. Smallholder farmers' knowledge, perception and management of rice blast disease in upland rice production in Tanzania. Journal of Agricultural Science. 10(7):137-145. ISSN 1916-9752. E-ISSN 1916-9760. Doi:10.5539/jas.v10n7p137.

Hufstetler E. V., Boerma H. R., Carter T. E. Jr., Hugh J. E. 2007. Genotypic variation for three physiological traits affecting drought tolerance in soybean. Crop Science. 47(1):25-35.

Islam A. H. M. S., Schreinemachers P., Kumar S. 2020. Farmers' knowledge, perceptions and management of chili pepper anthracnose disease in Bangladesh. Crop Protection
133:105-139.

https://doi.org/10.1016/j.cropro.2020.105139.

Lal R. 2009. Soil degradation as a reason for inadequate human nutrition. Food Security. 1:45-57.

Mbanya W. 2011. Assessment of the Constraints in Soybean Production: A Case of Northern Region, Ghana. Journal of Developments in Sustainable Agriculture. 6(2):199-214.

Medat N. R., Singh N., Kuthe S., Jigar G. 2016. Constraints in Soybean Production and Marketing Faced by the Farmers in South Gujarat. Advances in Life Sciences. 5(18):7381-7383. Print: ISSN 2278-3849.

Ministère du Cadre de Vie et du Développement Durable (MCVDD). 2020. Zones agro-écologiques de la République du Bénin. Retrieved September 29, 2020, from https://www.changementsclimatiques.bj/actuali tés/zones-agro-ecologiques-de-la-republiquedu-benin.html.

Mohammed A-R. S., Al-hassan S., Jatoe J. B. D. 2018. An overview of constraints to soybean production in the northern region of Ghana. UDS International Journal of Development. 5(1):32-40. ISSN: 2026-5336.

Norris R. F. 1999. Ecological implications of using thresholds for weed management. Journal of Crop Production. 2(1):31-58.

Oerke E. C., Dehne H. W. 2004. Safeguarding production losses in major crops and the role of crop protection. Crop Protection. 3:275-285.

Otitoju M. A., Arene C. J. 2010. Constraints and determinants of technical efficiency in mediumscale soybean production in Benue State, Nigeria. African Journal of Agricultural Research. 5(17):2276-2280. ISSN 1991-637X.

Prathuangwong S., Amnuaykit K. 1987. Studies on tolerance and rate reducing bacterial pustule of soybean cultivars/lines. Kasetsart J. 21: 408420.

Prathuangwong S., Suyama K., Fujii H., Negishi H. 2001. Analysis of Xanthomonas campestris pv. glycines from Soybean using simple serological procedures. Detection and diagnosis. Plant Pathogenic Bacteria. pp 397-405.

Riley M. B., Williamson M. R., Maloy O. 2002. Plant diseases diagnosis. The plant health instructor. DOI 10.1094/PHI-I-2002-1021-01.

Schreinemachers P., Balasubramaniam S., Boopathi N. M., Ha C. V., Kenyon L., Praneetvatakul S., 
Sirijinda A., Le N. T., Srinivasan R., Wu M. H. 2015. Farmers' perceptions and management of plant viruses in vegetables and legumes in tropical and subtropical Asia. Crop Protect. 75:115-123.

https://doi.org/10.1016/j.cropro.2015.05.012.

Shahbandeh M. 2020. Global oilseed production 2019/20, by type. Retrieved from https://www.statista.com/statistics/267271/worl dwide-oilseed-production-since-2008/.

Strange R. N., Scott P. R. 2005. Plant disease: a threat to global food security. Annual Review of Phytopathology. 43:83-116.

Tonon D. E. H., Zannou A., Sikirou R., Adomou A., Zinsou V., Boukari S., N'djolossè K. 2018. Les pertes économiques dues à l'anthracnose de l'anacardier au Bénin. European Scientific Journal. 14(15):127-138. ISSN: 1857-7881. (Print) e-ISSN 1857-7431. Doi: 10.19044/esj.2018.v14n15p127

Vivian R., Reis A., Kálnay P. A., Vargas L., Carolina A., Ferreira C., Mariani F. 2013. Chapter 3: Weed Management in Soybean - Issues and Practices. In: Soybean - Pest Resistance. 4484. http://dx.doi.org/10.5772/54595.

Zinsou V. A., Afouda L. A. C., Sikirou R., Dannon F. H., Dossou L., Ahohuendo B. C. 2015a. Distribution spatiale de la bactériose du soja (Xanthomonas axonopodis pv. glycines) dans la savane soudanienne du Bénin. Bulletin de la Recherche Agronomique du Bénin (BRAB). 77:17-26. En ligne (on line) sur le site web http://www.slire.net. ISSN: 1840-7099. ISSN sur papier (on hard copy):1025-2355.

Zinsou V. A., Afouda L. A. C., Zoumarou-Wallis N., PateBata T., Dossou L., Götz M., Winter S. 2015b. Occurrence and characterisation of Xanthomonas axonopodis pv. glycines, causing bacterial pustules on soybean in the guinea savanna of Benin. Afr. Crop Sci. J. 23:203-210.

Zinsou V. A., Zoumarou-Wallis N., Afouda L. A. C., Pate Bata T., Kora Sabi A., Dossou L., Afloukou F., Ahohuendo B. 2015c. Effet des dates de semis sur les niveaux de sévérité de la pustule bactérienne (Xanthomonas axonopodis pv. glycines) de soja (Glycine max) au Nord Bénin. Int. J. Biol. Chem. Sci. 9(5):2377-2384. ISSN 1997-342X (Online), ISSN 1991-8631 (Print).

Zinsou V. A., Afloukou F., Sekloka E., Dannon F. H., Zoumarou-Wallis N., Afouda L. A. C., Dossou L., 2016. Sélection des variétés de soja pour la résistance à la pustule bactérienne au Bénin. Tropicultura. 34:69-79. 